Article

\title{
Managed Globalization 2.0: The European Commission's Response to Trade Politicization
}

\author{
Patricia Garcia-Duran ${ }^{1}$, Leif Johan Eliasson ${ }^{2, *}$ and Oriol Costa ${ }^{3}$ \\ ${ }^{1}$ Department of Economic History, Institutions and Policy and World Economy, University of Barcelona, 09034 Barcelona, \\ Spain; E-Mail: patriciagarciaduran@ub.edu \\ 2 Department of Political Science and Economics, East Stroudsburg University, East Stroudsburg, PA 18301, USA; E-Mail: \\ jeliasson@esu.edu \\ ${ }^{3}$ Faculty of Political Science and Sociology, Universitat Autònoma de Barcelona, 08193 Cerdanyola del Vallès, Spain; E-Mail: \\ oriol.costa@uab.cat
}

* Corresponding author

Submitted: 18 October 2019 | Accepted: 17 February 2020 | Published: 31 March 2020

\begin{abstract}
Several studies have sought to explain the politicization of European Union's (EU) trade policy during negotiations on the Transatlantic Trade and Investment Partnership (TTIP) and the Comprehensive Economic and Trade Agreement between the EU and Canada (CETA). This article contributes to the literature on the politicization of trade by assessing how politicization is addressed by those tasked with the content and implementation of trade policy, namely the European Commission (hereafter Commission). We identify the origin and definition of managed globalization (MG), and thereafter identify, through a qualitative content analysis of EU Trade Commissioners' speeches from 2013 to late 2017, how the doctrine re-emerged as the leitmotif of EU trade policy. The Commission's initial response to civil society organizations' contestation over TTIP and CETA was to insist on the economic benefits of the agreements. As contestation intensified, we find indirect references to MG, as the Commission focused on clarifying that upholding European values was equally important to market access in EU trade policy. Then, from late 2016 until late 2017, the Commission's messaging was directed primarily at populist fears of trade and globalization; emphasizing that protectionism was unnecessary, and that globalization could be controlled, culminating in the emergence of explicit references to MG. The article expands on existing research on MG by identifying trade politicization as a factor that prompted a modification and expansion of the MG doctrine and its use, while also discussing some accompanying policy changes.
\end{abstract}

\section{Keywords}

Comprehensive Economic and Trade Agreement; European Commission; managed globalization; politicization; trade; trade policy; Transatlantic Trade and Investment Partnership

Issue

This article is part of the issue "Politicization of EU Trade Policy across Time and Space" edited by Dirk De Bièvre (University of Antwerp, Belgium), Oriol Costa (Universitat Autònoma de Barcelona, Spain/IBEI, Spain), Leif Johan Eliasson (East Stroudsburg University, USA) and Patricia Garcia-Duran (University of Barcelona, Spain).

(C) 2020 by the authors; licensee Cogitatio (Lisbon, Portugal). This article is licensed under a Creative Commons Attribution 4.0 International License (CC BY).

\section{Introduction}

Several studies have sought to explain the politicization of European Union's (EU) trade policy during negotiations on the Transatlantic Trade and Investment
Partnership (TTIP) between the US and the EU, and the Comprehensive Economic and Trade Agreement (CETA) between the EU and Canada (e.g., Laursen \& Roederer-Rynning, 2017; Young, 2018), as well as the European Commission's (hereafter Commission) re- 
sponse (Eliasson \& Garcia-Duran, 2019; Siles-Brügge, 2018; Young, 2019). This article contributes to these efforts, but more importantly, it focuses on the larger question of the politicization of trade by arguing that the Commission's response to mobilization against TTIP and CETA was neither completely new, nor specific to these agreements, but rather a modification and expansion of a previously applied doctrine. This matters because the trade doctrine adopted by the Commission is today intended to not only quell, but also incorporate, expressed concerns about the expansion of new issues in trade negotiations; it is also used to address rising populism and concerns about globalization.

In this article we argue that the EU responded to increased politicization by invoking, modifying, and adopting a doctrine originating in 1999. Managed globalization (MG) initially emerged in 1999, in a different context, and was applied by the Commission for some years thereafter. We tap into the literature about that period to define $M G$, and then explore the EU's messaging during and after TTIP negotiations (although negotiations on CETA began prior to TTIP negotiations, CETA was not politicized until linked with TTIP).

We show that the Commission's rhetorical response to the most politicized trade negotiations in EU history (on TTIP) was incremental, with three distinct phases, leading to an invocation and solidification of a modified $M G$ as the Commission responded to contested trade policies, rising populism, and fears of globalization. Explicit references to a modified MG emerged just as the TTIP negotiations were frozen, indicating that the Commission deemed it a useful way of signaling a permanent shift in trade policy. In this context an explanatory note is appropriate: A doctrine is a belief system that may guide policy; a policy is the principles and the rules adopted by an organization; a strategy is a way of conveying and implementing a policy.

The next section presents politicization and responsiveness, and justifies our argument on theoretical grounds, while section three explains the methodology. The analysis is presented in sections four and five. Section six concludes.

\section{Rhetorical Responses to Politicization and the Managed Globalization Doctrine}

The objective of this article is to improve our understanding of the Commission's response to politicization over TTIP and CETA. We argue that: 1) the Commission's response was part of a rhetorical counter-strategy, and 2 ) that the response was grounded in the MG doctrine introduced by Trade Commissioner Pascal Lamy in 1999. Our study contributes to the literature on the evolution of the EU's trade policy pertaining to both values and market access (Drieghe \& Potjomkina, 2019). Our research also complements, and partly challenges, the analysis carried out by Young (2019), who, when comparing the EU's 2010 and 2015-2017 trade strategies, ar- gues that the Commission "over-generalized from an extreme case" and pursued a policy "characterized more by continuity than by change" (p. 3). While we do not assess whether the Commission's response to politicization was sufficient to permanently address civil society's concerns over trade (cf. Eliasson \& Garcia-Duran, 2019), we take a slightly longer historical perspective, which further enhances our understanding of how the Commission responded to trade politicization in the context of TTIP negotiations and their aftermath.

An analysis of the Commission's response is also relevant to the literature on the politicization of EU integration. For some, the politicization of European integration spells the end of the permissive consensus and the beginning of an era of "constraining dissensus" (Hooghe \& Marks, 2009), while others (Beck, 2013; Hix, 2006) see politicization as a democratic necessity and a precondition for the legitimacy of further European integration. Our case study provides insights on how the targets of politicization deal with the challenging relationship between politicization and legitimacy.

\subsection{Politicization and Responsiveness}

The literature shows that politicization includes rhetorical strategies, and that it is a cause of change in international institutions and the EU. Drawing on the definitions outlined by de Wilde (2011) and Gheyle (2019), we define trade politicization as an increase in the salience of trade negotiations, institutions, and rules, a rise in the number and type of actors mobilizing and participating in debates on trade policy, and the polarization of their opinions.

From the time the negotiations on TTIP were announced, there was a steadily rising chorus emanating from civil society organizations (CSOs) arguing that the agreement threatened to undermine EU standards and safety regulations, as well as governments' abilities to regulate in the public interest (De Ville \& Siles-Brügge, 2016; Eliasson \& Garcia-Duran, 2017). CSOs, some labor unions, and a few political parties, sought to convince the public that TTIP would harm product safety, public policies, and democracy (see also van Loon, 2020, in this thematic issue). Opposition emerged across Europe, though concentrated in the western half of the European continent and the UK. Many groups staged their own events, but many also learned from, and most coordinated with, others, sometimes under the pan-European heading StopTTIP! (Eliasson \& Garcia-Duran, 2019; Young, 2017).

CSOs largely refrained from attempting to undermine proponents' claims of the economic and geopolitical benefits of TTIP, choosing instead to focus on the fear of losing precious European achievements, such as high food and safety standards, and the welfare state. TTIP was presented as a trade-off between neo-liberalism (or "wild-west capitalism") and "popular sovereignty" (Friends of the Earth Europe, 2016; cf. IG Metal, 2014). CSOs framed Investor State Dispute-Settlement (ISDS)- 
a long-established practice intended to ensure that foreign investors have access to a de-politicized legal process to pursue compensation, but not legislative changes, through third-party arbitration when a host country's government violates the terms of an investment treatyin TTIP as a carte blanche for US corporations to sue European governments over any public policy that could reduce corporate profits, such as new environmental or public health laws. Both taxpayers and public policies would therefore be 'on the hook' of US companies' actions (Eliasson \& Garcia-Duran, 2019, pp. 61-68). Transparency (or rather, the lack of) was another issue chosen to signal the detrimental effects of TTIP; the argument being that nothing negotiated by representatives behind closed doors can produce a good agreement (De Ville \& Siles-Brügge, 2016; Gheyle \& De Ville, 2017).

CSOs consistently paired big business or corporations with something negative, implying that the Commission was unable to withstand US pressure, thus jeopardizing European standards (e.g., Seattle to Brussels Network, 2015). TTIP was portrayed by the Corporate Europe Observatory as a losing proposition for Europeans, a "vehicle to facilitate deregulation" threatening each side's democratic right to regulate "even when doing so results in divergent standards that businesses may find inconvenient" (Corporate Europe Observatory, 2013a). TTIP would "open the floodgate to GMOs [genetically modified organisms]" and "TTIP will lower regulations on food safety...and will lead to more industrialized, intensive food production that undermines the health of people and the planet. Trade policy should be for the benefit of people and the environment, not corporations" (Corporate Europe Observatory, 2013b, p. 1, 2014, p. 8). The message sent throughout 2013-2016 was that TTIP meant sacrificing European values and standards (cf. Buonanno, 2017; Young, 2017).

Zürn (2014) argues there is a sizeable degree of responsiveness by international institutions to politicization, thus we should expect the EU to respond to this feargrounded rhetorical strategy with some form of counterrhetoric. The EU is considered a "hothouse" for participation of different types of actors (Peterson, 1995, p. 69), and we expect this to strengthen the effect of politicization on the incentive structure of policy-makers, making them more responsive. De Bruycker (2019, p. 1) using a panel data analysis on EU responsiveness finds that "under politicized conditions, the adoption of EU policy decisions is preceded by increased public support and followed by decreased public support for EU policy change." This indicates that, in the face of politicization, decisionmakers adjust policy to social demands (policy responsiveness), after which the public again adjusts their demands in light of those policy changes (public responsiveness; Zürn, 2014, pp. 59-60). Such changes can be fostered by accountability mechanisms, including close scrutiny by voters and elected officials; again, given the EU's structure, we should expect it to be more responsive to politicization than (other) international institutions.

\subsection{Managed Globalization and Politicization}

CSOs contested trade and globalization in late 1999 and early 2000, before, during, and after the World Trade Organization's (WTO) ministerial meeting in Seattle (the "Battle of Seattle," e.g., Scholte, 2000). As Abdelal and Meunier (2010, p. 355) argue, "the anti-globalization movement was gaining traction in public opinion with its widely publicized successes at the WTO conference in Seattle in 1999 and later at the World Social Forum." As a result, "other European countries embraced the French vision that globalization ought to be accompanied by new regulations and flanked by policies to soften its impact" (Abdelal \& Meunier, 2010). The protests were at that time directed primarily at the WTO rather than the EU, but as a major player (along with the US, Japan, and Canada) it provoked a significant response by the Commission.

Pascal Lamy, Trade Commissioner from 1999 to 2004, introduced the term MG in his hearing at the European Parliament in September 1999, and was subsequently able to make it "the guiding doctrine of EU trade policy" (Meunier, 2007, p. 910). The adoption of MG also served to calm internal tensions about EU trade policy between those advocating trade liberalization and those concerned with the preservation of public standards, including demands for trade protection (Meunier \& Nicolaïdis, 2006, p. 921). Existing European preferences on food safety, cultural diversity, public provision of education and health care, or welfare rights, couldit was argued-legitimate protection against foreign entrants, and "such a philosophy [of protection]...might be the ultimate condition for sustaining public support for an overall strategy of relatively open-access to EU markets" (Meunier \& Nicolaïdis, 2006, p. 922). However, after 2004, MG ceased appearing in speeches and strategy papers, and was "replaced in 2006 by shorterterm, more trade-centred and mercantilist objectives" (Meunier, 2007, p. 906). The primary goal of EU trade policy was no longer the "more remote goal of managing globalization" but instead "creating markets abroad for European companies" (Meunier, 2007, p. 916). While still affirming the primacy of multilateralism, the EU's abandoned its moratorium on bilateral trade agreements, and the stated priority was no longer to balance openness with rules, but rather to ensure market access.

\section{Managed Globalization as a Response to Politicization}

We analyze the Commission's rhetoric on TTIP, CETA, and trade policy in general from 2013 to 2017. This section presents the methodology, while justifying the choices made.

\subsection{The Commission's Rhetorical Response}

We analyze the Commission's communication on TTIP and CETA negotiations in particular, and on EU trade pol- 
icy in general, from around the time TTIP negotiations were announced in January 2013 until September 2017. The analysis covers 79 speeches (European Commission, 2012-2016, 2016-2017; see the Supplementary File for a list of all speeches, in this article they are referenced only by "European Commission, month day, year"), representing more than $50 \%$ of speeches between January 2013 and October 2016, and all 22 speeches on EU trade policy between November 2016 and September 2017. We end in September in 2017 because it was one year after TTIP negotiations ended-providing sufficient time to capture any changes in rhetorical strategy vis-à-vis ongoing negotiations, as well as the rise in the populist backlashes against trade and globalization. The Commission also published its first report on the implementation of the 2015 trade strategy, Trade for All (European Commission, 2015), that month. Thus, we should be able to ascertain whether the MG doctrine had taken hold by fall of 2017.

We chose to analyze speeches made by the Trade Commissioner because the Commission oversees all trade negotiations, and the Trade Commissioner is the official representative of and spokesperson on EU trade. What the Commissioner says should reflect where the Commission stands and what it will do on trade. We do not distinguish between Trade Commissioners (Karel De Gucht was Trade Commissioner in 2013 and for most of 2014, while Cecilia Malmström assumed office in November 2014) because the objective is to assess the Commission's response rather than the impact of each Commissioner.

We carry out the analysis using qualitative content analysis. This method was chosen because it identifies key discursive elements through a deductive rather than inductive procedure, while adopting an interpretative focus on framing and changes in discourse (Kohlbacher, 2006). To analyze the framing and changes in discourse we draw on Hirschman (1991) and Brink (2009). These scholars identify different rhetorical strategies. Hirschman (1991) distinguishes between three types of rhetorical responses, or "rhetoric of reaction" used by opponents of a proposed change or reform. The "perversity thesis" assumes that a proposal would only "serve to exacerbate the condition one wishes to remedy" (p. 7) because there will be unintended consequences or sideeffects due to imperfect foresight. The "futility thesis" holds that attempts at social transformation would fail to change society because the basic structures of society are unchangeable; "human actions pursuing a given aim are nullified" (p. 72). Finally, the "jeopardy thesis argues that the cost of the proposed change or reform is too high as it endangers some previous, precious accomplishment" (p. 7); while the proposed change may be desirable in itself, it involves unacceptable costs (p. 81).

When opponents use a thesis based on a fear of losing benefits inherent in the status quo, as in the case over TTIP (a "jeopardy thesis"), recipients may resort to three types of rhetorical responses: intransigent, democracy friendly, and functional; the second and third type of messaging being more conciliatory than the first. The "intransigent" rhetoric includes "mutual support" (which is positive messaging; actions will generate benefits without jeopardizing the status quo), and "dangers of inaction" (negative messaging; inaction results in harm). "Democracy friendly" rhetoric entails conciliation, moving beyond intransigent postures, and engaging in deliberation. This represents a "mature" approach, where the risks of both action and inaction are "canvassed, assessed, and guarded against to the extent possible," and where uncertainty is recognized (Hirschman, 1991, p. 153). A "functional" rhetorical approach (Brink, 2009) is when supporters or advocates use the language and standpoints of opponents, but without changing policy preferences. Such a response differs from a democratically friendly one, in that rather than conveying a willingness to change the policy or negotiating position, supporters would continue claiming the same or a similar position, but apply language used by opponents. In the TTIP case where opponents positioned themselves as the protectors of European values (exigent standards) and democracy (public policies), a functional response would be to accept and state that values and democracy should be at the forefront of EU trade policy.

Thus, we differentiate between intransigent positive messaging (e.g., TTIP will improve status quo), intransigent negative messaging (e.g., status quo in danger without TTIP), conciliatory messaging (e.g., TTIP's costs should be considered) and functional messaging (e.g., European values and democracy are more important than material or geopolitical benefits), which we identify in the qualitative content analysis. Due to opponents' focus on the need to protect EU values, the more functional or democratically friendly the messaging, the more likely the invocation of the MG doctrine. We find that the Commission was consistently conciliatory regarding ISDS, while its rhetoric on the other issues of contention (economic and geopolitical benefits, and EU standards) shifted from mainly intransigent (through both positive and negative messaging), to increasingly functional rhetoric.

\subsection{Operationalizing the Managed Globalization Doctrine}

To assess whether there is evidence of the MG doctrine in the Trade Commissioner's speeches from 2013 to November 2017, we need to operationalize the MG doctrine. To do so, we draw on the work of Meunier (2007) and Jacoby and Meunier (2010).

According to Meunier (2007, p. 906), MG refers to an encompassing doctrine that subordinates trade policy to a variety of non-trade objectives, such as multilateralism, social justice, and sustainable development. As such, MG means "going beyond the simple removal of regulations and making some effort to shape and regularize the competitive order," thus establishing "rule-based globalization" (Meunier, 2007, pp. 303-304), which "shows 
the voters that politicians are firmly in control" (p. 301). Jacoby and Meunier (2010, p. 302-303) add that this doctrine is placed between the extremes of protectionism and complete laissez-faire ("ad hoc globalization"), thus implying an effort to both tame and harness globalization. The Commission's rhetorical compatibility with MG is also assessed by comparing it against the five characteristics of MG outlined by Meunier (2007). In practical terms, Meunier argues, MG means building a set of constraining trading rules, promoting multilateralism, widening the definition of trade issues subject to rule-making, exporting the EU model, and redistributing the benefits and costs of globalization.

In the following sections we first look for messages regarding the objectives of EU trade policy in the Trade Commissioner's speeches, focusing on the messages' positioning on the laissez-faire/protectionism continuum, and the strategy employed by the Commission. The MG doctrine is not present if the objective is at one of the extremes; either pure market access or no trade agreement. If values are placed at least on the same level as economic interests, we accept that the MG doctrine is being used by the Commission. We find that while the Commission only explicitly began referring to MG after the freezing of TTIP negotiations in late 2016, MG had already implicitly returned as a guiding principle for trade policy in 2015, manifest in Trade for All (European Commission, 2015). Section five goes further, examining the Commission's approach and messaging in regards the five aforementioned characteristics of MG. We find that while the Commission proposed a trade policy consistent with these characteristics, the promotion of multilateralism is implicit, through bilateralism, and there is a new preoccupation with trade defense instruments.

\section{The Directorate General for Trade's Response to Politicization from 2013 to 2017}

The Commission's initial messaging-when contestation began-was devoid of any references to MG. The focus was on economic benefits (i.e., on market access). Thereafter, as contestation intensified in late 2014 and evolved into the politicization of trade policy, the Commission used language more consistent with MG. The focus shifted to countering CSOs' fears that TTIP endangered European values. We find that the Commission only explicitly began referring to MG after the freezing of TTIP negotiations in late 2016, and then mainly when countering demands for protectionism (fear of globalization) by populist parties, but that MG had already implic- itly returned as a guiding principle for trade policy in 2015. This shift towards the MG doctrine is consistent with the evolution in the type of rhetoric used by the Commission. As summed up in Table 1, the use of MG language coincides with an increasing use of functional messaging.

\subsection{3-2014: A Focus on Economic Benefits}

TTIP was promoted as bringing economic benefits and providing economic growth, thanks to 'scale' (the size of the partners' commercial relationship would create a multiplier effect for all new liberalization), integration (extensive economic interpenetration means better integrated value chains), confidence (companies would be able to plan for the future), and because the costs of inaction (to the status quo) would be high (Eliasson \& Garcia-Duran, 2019, p. 83). In 2013, prospective economic benefits were quantified, as were TTIP's impact on third countries (European Commission, March 2, 2013). In 2014, the Commission presented specific examples of economic benefits, and began emphasizing how small and medium enterprises were going to benefit (e.g., European Commission, May 22, 2014).

The Commission also progressively enlarged the number of arguments it used to promote TTIP in the face of $\mathrm{CSOs}^{\prime}$ claims that the agreement would radically change the status quo for European standards and democracy. Countering opponents' arguments, the Commission maintained that the status quo was not an option, because both partners were simultaneously negotiating and signing other bilateral trade agreements (European Commission, December 5, 2012). If the US and the $\mathrm{EU}$ were unable to reach agreement on regulatory convergence, then "others" would exercise leadership in regulatory matters (European Commission, October 10, 2013, p. 6). Moreover, regulatory convergence would not lead to a race to the bottom because "the world's most advanced, most revolutionary, experiment in regulatory cooperation" - the European Single Marketshowed that "there doesn't need to be a trade-off between high standards and open markets" (European Commission, October 10, 2013, p. 3). In 2014, TTIP was said to allow the EU to shape world norms because "if we want to continue to shape the norms, rules, standards and disciplines that are so important in a globalized economy, we have to realise that we cannot do this without partners" (European Commission, May 22, 2014, p. 4).

The Commission was more conciliatory regarding ISDS. This issue only started appearing in speeches around the same time as the Commission's commitment

Table 1. Type of messaging and consistency with MG.

\begin{tabular}{lll}
\hline Period & Language consistent with MG & Type of messaging \\
\hline $2013-2014$ & No & Mainly intransigent \\
$2015-2016$ & Yes, implicitly & Shift towards functional \\
$2016-2017$ & Yes, explicitly & Mainly functional \\
\hline
\end{tabular}


to making the negotiation "as transparent and open to public scrutiny as possible" (European Commission, April 10, 2014, p. 5). The purpose of a public consultation launched by the Commission in 2104 was "to create a new, improved type of investment agreement" (European Commission, April 10, 2014, p. 4). In May 2014, while clearly supporting the need for investment protection in TTIP, the Commission accepted "that there is room for debate, interpretation or improvement" (European Commission, May 22, 2014, p. 2) and emphasized that "it is our chance to set a model for future agreements all around the world" (p. 3).

As protests by CSOs intensified, the messagingwhile still mainly intransigent and focused on the economic benefits of TTIP-shifted from promoting TTIP's benefits for growth and jobs to consumer benefits. The agreement was said to "give consumers better access to a wider range of high quality goods and services at better prices" (European Commission, May 22, 2014, p. 3). In November 2014, the Commission implied conciliation when stating that "the only valid measure of the success of this negotiation will be whether it improves people's lives"; TTIP can do so by addressing "the full range of consumers' needs" (European Commission, November 18, 2014, pp. 1, 3).

\subsection{January 2015-November 2016: Implicit Managed Globalization}

By early 2015, the Commission's rhetoric was increasingly conciliatory regarding investment protection (downplaying its risks and emphasizing its necessity in protecting European business, while agreeing that the process could be improved). There was also positive (e.g., TTIP would improve the status quo) and negative (e.g., the status quo would be in danger without TTIP) intransigent messaging in response to CSOs' arguments about TTIP lowering standards. The same applied when emphasizing the geopolitical and economic benefits of TTIP (Eliasson \& Garcia-Duran, 2019). However, the tenor of the messaging began to change; functional rhetoric became more prevalent as the Commission attempted to lessen the polarization over TTIP.

Attempts at addressing fears of TTIP now included using opponents' language and positions to stress the overriding importance of defending European values and democracy, while simultaneously defending TTIP (see Garcia-Duran \& Eliasson, 2018a). Trade for All, the Commission's October 2015 trade policy strategy, exemplifies this effort (European Commission, 2015). The strategy was heralded as evidence that the Commission was addressing people's concerns by redesigning the EU's trade policy strategy:

We have learned from the TTIP debate. On the one hand, we have learned that people do want more trade.....But on the other hand, we have learned that they don't want to compromise on the core principles of European society in order to get those benefits.....In our new approach, trade is not just about our economic interests but also about our values....Actively managing change is therefore essential to making sure the benefits of globalisation are fairly distributed and negative impacts are mitigated. The social consequences of market opening must be addressed. (European Commission, October 19, pp. 5-6, 11)

The Commission stressed that the EU can export its values and shape globalization through its trade agreements, using access to its market as a recognized bargaining chip to obtain changes in the domestic arena of its trading partners (European Commission, October 10, 2015 , p. 1, November 9, 2016, p. 2). The Commission explained that "we should use it to promote European values like sustainable development, human rights, fair and ethical trade and the fight against corruption" (European Commission, 2015, p. 6, cf. February 25, 2016 and March 15, 2016). The new trade strategy was based on three core principles: effectiveness, transparency, and values, which address the "widespread concern that trade policy is more about the large companies and the investors than about individual European citizens.... [It is] a trade policy which is in tune with European values" (European Commission, November 30, 2015, pp. 4-5). This aligned with the core of MG. The Commission recognized that people "need reassurance that we will not use trade agreements to put economic advantage above our other goals, like consumer and environmental protection or the rights of workers," while promoting "the kind of trade agenda that can both find legitimacy among EU citizens and deliver economic results" (European Commission, September 22, 2016, pp. 2, 4).

Within this framework, the Commission applied the concept of a "progressive trade agreement," hailing CETA as its standard bearer-the term was initially used in 2015 by the Obama administration to describe the Transpacific Partnership Agreement, and then in August 2016 by Sigmar Gabriel, Vice Chancellor of Germany, referring to CETA. CETA was said to be a progressive trade agreement that guarantees transparency ("negotiators in close contact with civil society and closely watched over by Member States and the European Parliament") and the protection of public services ("There is no obligation to privatize anything. And no block on renationalizing an already privatized service"); the right regulatory cooperation ("enshrines our right to regulate in the public interest. And, while it encourages regulatory authorities to cooperate, it does not oblige them to do so"), and investment protection ("much-needed reform of international investment protection agreements") (European Commission, September 20, 2016, p. 4). The Commission argued that CETA would allow the EU to benefit from trade and investments, while prioritizing and exporting high EU standards, and agreeing to rules that tame unbridled competition (and which could set standards for other agreements). 


\subsection{November 2016-September 2017: Explicit Managed Globalization}

By balancing free trade with defending values, the language used since 2015 fits the MG doctrine. However, it was only after TTIP negotiations paused in November 2016 that the Commission moved from 'progressive trade agreements' to 'managed globalization.' This was concurrent with a shift in both the source (more parties and labor unions) and focus (away from trade agreements to trade and globalization generally) of contestation, as anti-TTIP and anti-CETA protests waned, but did not vanish; anti-CETA protests continued in Brussels during the agreement's 2017 ratification process.

Explicit reference to MG first reappears in a speech on November 9th, tellingly titled "Shaping Globalisation through EU Trade Policy," where the Commissioner argues that "shaping globalisation is also about ensuring that people in Europe feel they have influence over the global rules that are affecting them" (European Commission, November 9, 2016, p. 1). The first reference to populism appeared two months prior, and by late November the Commission acknowledged that the political realities of the time included both people who perceived themselves economically disadvantaged by globalization (and fed the anti-trade populist and nationalist movements), and people who were skeptical about a number of trade agreements and negotiations because they saw them as endangering European values (European Commission, November 29, 2016). In subsequent speeches, references to protectionist demands by populists complemented or substituted for CSOs' demands of preserving European values. The Commission's answer came through functional rhetoric referencing MG.

The Commission thus shifted the emphasis of its discourse from primarily value preservation to dealing with globalization, arguing that trade openness comports with EU interests and ideas, "trade must be seen to deliver. By using trade policy as a vehicle for our values, we can shape globalization, rather than merely submitting to it, or letting others shape it for us" (European Commission, January 24, 2017, p. 4). The emphasis was also on the need for an open, progressive, trading system, without compromising standards or values, "while shaping globalization" (European Commission, March 28, 2017, p. 1, 4). The Commission's September 2017 progress report on Trade for All emphasizes how the 2015 strategy should continue guiding the EU's approach to making "globalization work for all Europeans" (European Commission, 2017a, p. 2). The report explains how the EU is using all available tools to implement its trade strategy and enforce its commitments, while "shaping globalization into an opportunity" (European Commission, 2017a, p. 4). In an accompanying communication the Commission also proposes new initiatives to proactively shape and manage global trade "to ensure it is fair, projects values and remains firmly an- chored in a rules-based system" (European Commission, 2017b, p. 2).

\section{The Commission's Approach and Its Fit with Managed Globalization}

In this section we assess how MG, as used by the Commission since 2015, comports with the five practical characteristics of the MG doctrine: building a set of constraining trading rules, promoting multilateralism, widening the definition of trade issues subject to rule-making, exporting the EU model, and redistributing the benefits and costs of globalization both within the EU and at the global level. We present the results without distinguishing between the periods of implicit and explicit references to MG because we find that the Commission's rhetoric generally fits these characteristics even before November 2016. However, through greater acceptance of bilateralism, as well as a re-enforcement of trade defense measures, we identify a modification of the EU's application of the doctrine.

The Commission continuously communicated the need for redistributing the costs and benefits of globalization both within the EU and at the global level. Trade for All meant "making sure the benefits of trade are widely spread" by helping fair trade, worker adaptation, small firms' provisions, and trade opportunities for EU developing partners (European Commission, October 19, 2015 , p. 6). The Commission came to advocate a revision of the European Globalization Adjustment Fund (to assist with worker adaptation), longer transition periods for the most sensitive products, and closer ties between trade policy and development through the Economic Partnership Agreements, Everything but Arms, Aid for Trade, and the General System of Preferences of the EU (European Commission, November 7, 2015, February 25, 2016, September 22, 2016, November 9, 2016, January 24, 2017).

The Commission also advocated strong, empowered international institutions with clear rules of the game and an institutional architecture to monitor those rules through its support for a rules-based ISDS system. While addressing concerns about globalization and corporate power over governments, the Commission progressively built an argument that TTIP constituted an opportunity to modernize investment protection (European Commission, June 22, 2015, November 17, 2015 , January 12, 2016), before deciding to reject a traditional ISDS in TTIP and instead promoting a new international court that would be fair, transparent, and accountable (European Commission, September 14, 2016, January 24, 2017, February 27, 2017; see also European Commission, 2017a, 2017b; a mandate was also provided by the European Parliament in 2018), a system judged compatible with EU by the EU Court of Justice on April 30, 2019.

The EU used access to its market as a bargaining chip in order to obtain changes in the domestic 
arena of its trading partners: "We are also using the importance of our economy to shape globalisation" (European Commission, November 9, 2016, p. 2). The Commission clearly recognized that the EU can export its values and shape globalization through its trade agreements (European Commission, October 10, 2015, p. 1). "We should use it to promote European values like sustainable development, human rights, fair and ethical trade and the fight against corruption" (European Commission, November 30, 2015, p. 6, cf. February 25, 2016, March 15, 2016).

Regarding multilateralism, the Commission expanded the number of issue areas it included when explaining how its trade policies would best serve EU citizens. Long a champion of multilateralism, its primacy appeared to wane with each bilateral agreement pursued by the EU. Bilateralism is now touted as a pathway (complementing multilateralism) to incrementally spread EU standards globally (Garcia-Duran \& Eliasson, 2018b). The EU trade strategy still involves "working for progress at the WTO. [But] it also involves a comprehensive set of negotiations for bilateral free trade agreements" (European Commission, June 1, 2015, p. 2, see also March 23, 2015), and since progress in the multilateral system "has been too slow...the EU has put new emphasis on bilateral free trade agreements with key partners since 2006" (European Commission, February 25, 2016, p. 4-5). Plurilateral agreements are also accepted: "If it's a choice between making progress with a smaller number of partners or no progress at all, then we will choose to move forward-plurilaterally" (European Commission, April 26, 2016, p. 2, also May 2, 2016). The shift towards bilateral and plurilateral agreements is compatible with MG since "bilateral and regional deals like TTIP can support the multilateral system by acting as policy laboratories of sorts", and "We are building a network of agreements all across the world so that we can link into the world economy and build truly global value chains that will bring prosperity home" (European Commission, May 2, 2016, p. 3, September 14, 2016, p. 2).

As a result, bilateral (and plurilateral) agreements play a role in another of the MG characteristics, namely expanding the number of issues subject to rule-making in trade agreements. Immediately following the publication of Trade for All, the Commission promised to include "anti-corruption provisions in EU trade agreements," while also addressing services, digital trade, mobility, and labor rights (such as collective bargaining), and protecting endangered species (European Commission, October 19, 2015, p. 7, November 30, 2015, p. 4, March 15, 2016). One year later the Commission declared that "All new trade deals include chapters on trade and sustainable development, including labor rights and the environment" (European Commission, March 22, 2017, p. 2, cf. on November 9, 2016, and January 24, 2017). Table 2 summarizes our argument over how MG as applied from 2015 to 2017 related to its 1999 version.

Finally, another difference in the EU's explicit references to MG was the emphasis on trade defense instruments, which were strengthened in order to respond to unfair competition, while the Commission argued that more should be done to help workers adapt (European Commission, November 29, 2016, pp. 3-4, see also January 24, 2017, May 9 and 23, 2017, and European Commission, 2017a). In 2016 the Commission referred to a crisis in the steel industry provoked by excess Chinese capacity, and how in China "too often the state is more a participant than an independent regulator" (European Commission, March 10, 2016, p. 3). As one example of the staying power of this expansion to MG, European Commission President Jean-Claude Juncker explained in 2018 that "the EU believes in open and fair trade but we are not naïve free traders." "Make no mistake," he added, "we will do whatever it takes to defend European producers and workers when others distort the market or don't play by the rules" (European Commission, 2018).

\section{Concluding Discussion}

Our analysis of the European Commission's rhetoric regarding TTIP, CETA, and EU trade policy in general, from 2013 to 2017, indicates that the Commission response to trade politicization in 2015-2017 was part of a rhetorical counter-strategy, and that it was grounded in the MG doctrine. We identify three distinct periods in the Commission's rhetoric: from 2013 through 2014, early 2015 through mid-2016, and mid-2016 to

Table 2. MG doctrine characteristics.

\begin{tabular}{ll}
\hline MG doctrine characteristics & EU's application 2015-2017 \\
\hline $\begin{array}{l}\text { Redistributing the benefits and costs of globalization both within } \\
\text { the EU and at the global level }\end{array}$ & Present \\
Building a set of constraining trading rules & Present \\
Exporting the EU model & Present \\
Promoting multilateralism & Through bilateralism and plurilateralism \\
Widening the definition of trade issues subject to rule-making & Present \\
Not present & Re-enforcement of trade defense measures
\end{tabular}


(at least) September 2017. During the first period, the Commission was predominantly defending its trade policy and negotiations with the US on the basis of economic benefits-using predominantly intransigent messaging (TTIP would improve the status quo, and without TTIP the status quo would be in danger). In 20152016, the second period, the Commission responded to intensifying claims by CSOs that EU standards and values were in danger. Elements of the MG doctrine were used to lessen polarization, but without touting the doctrine. During this period there was also a shift in the messaging, from mainly intransigent to more functional (European values cannot be endangered). The third period entailed a reframed rhetoric directed primarily at populist arguments and demands for protectionism; the Commission's language was framed in explicit MG language, with emphasis on how trade serves European citizens, and globalization can be controlled (i.e., no need for protectionism). This reframed rhetoric was communicated mainly through functional messaging (using opponents' language and standpoints).

These results add to our understanding of the impact of politicization on trade policy, by showing how the Commission's rhetoric changed in response to mobilization. It therefore appears the Commission is seeking legitimation through ideas, that is, trying "to persuade citizens or other EU institutional actors of the EU's political responsiveness to citizens needs and demands" (Carstensen \& Schmidt, 2018, p. 761). Not only did trade politicization over TTIP elicit an expansive response from the Commission, but that response largely conformed to the MG doctrine as defined in section three. Nevertheless, the MG doctrine has been adapted to respond to the changing sources and focus of contestation during and after TTIP negotiations. While the shift from multilateralism to bilateralism and plurilateralism, and the new importance of trade defense measures could be interpreted by some as a shift towards protectionism, our assessment is quite different. The EU's contemporary and expanded application of the MG doctrine includes a recognition that a multilateral approach is not the primary means by which to manage globalization. Instead, bilateral and plurilateral agreements are pursued as stepping-stones to global, multilateral, rules and standards. Furthermore, 21st century geopolitical and economic shifts, and the protests they have birthed, have made strengthening and enforcing defensive trade measures a necessary part of rule-making.

Using the MG doctrine as a metric against which to assess the evolution of the Commission's approach to trade policy may thus be useful. When comparing EU trade strategies in 2010 and 2015-2017, Young (2019) concludes that there is more continuity than change. While we agree that the Commission's trade strategies and policies have always reflected certain values, there is a clear change in the rhetorical strategy pursued by the Commission. The adoption of the MG doctrine signals a willingness to re-balance the equilibrium between openness (market access) and rules, where the defense of certain values (principles) is now as prominent as market access.

The fact that explicit references to MG emerged just as the TTIP negotiations were frozen, and they persisted one year later, indicate that the Commission deemed it useful as a way of signaling a permanent shift its trade policy. Thus, by late 2017 a modified and expanded MG had become the EU's leitmotif on trade; only future research covering periods of less contentious trade negotiations can assess whether MG endures. What we have shown in this article is that politicization of trade affected the Commission's reaction, response, and messaging on trade, and ultimately its trade doctrine (guiding trade policy and strategy).

\section{Acknowledgments}

We would like to thank all participants at a 2018 workshop at Institut Barcelona d'Estudis Internacionals (IBEI), Barcelona, and the panelists at EUSA 2019 in Denver, Colorado, for helpful comments on previous versions of this article. We also thank the three anonymous reviewers for Politics and Governance for their valuable comments and suggestions. This work was supported by the National R+D Plan of the Spanish Ministry of Economy and Competiveness under Grant CSO2016-79205-P, “EU-NormCon, Normative Contestation in Europe: Implications for the EU in a Changing Global Order."

\section{Conflict of Interests}

The authors declare no conflict of interests.

\section{Supplementary Material}

Supplementary material for this article is available online in the format provided by the authors (unedited).

\section{References}

Abdelal, R., \& Meunier, S. (2010). Managed Globalization: Doctrine, practice and promise. Journal of European Public Policy, 17(3), 350-367.

Beck, U. (2013). German Europe. London: John Wiley \& Sons.

Brink, A. (2009). Hirschman's rhetoric of reaction: US and German insights in business ethics. Journal of Business Ethics, 89, 109-122.

Buonanno, L. (2017). The new trade deals and the mobilisation of civil society organizations: Comparing EU and US responses. Journal of European Integration, 39(7), 795-809.

Carstensen, M. B., \& Schmidt, V. A. (2018). Ideational power and pathways to legitimation in the euro crisis. Review of International Political Economy, 25(6), 753-778. 
Corporate Europe Observatory. (2013a). No to a corporate driven agreement. Corporate Europe Observatory. Retrieved from https://corporateeurope.org/ trade/2013/07/no-corporate-driven-agreement

Corporate Europe Observatory. (2013b). Who's scripting the EU-US trade deal? Corporate Europe Observatory. Retrieved from https://corporateeurope.org/ trade/2013/06/who-scripting-eu-us-trade-deal

Corporate Europe Observatory. (2014). TTIP: A recipe for disaster EU-US trade deal blocks future of good food and farming. Corporate Europe Observatory. Retrieved from https://corporateeurope.org/ sites/default/files/attachments/ttip_a_recipe_for_ disaster_booklet_dec_2014.pdf

De Bruycker, I. (2019). Democratically deficient, yet responsive? How politicization facilitates responsiveness in the European Union. Journal of European Public Policy. https://doi.org/10.1080/13501763.2019. 1622587

De Ville, F., \& Siles-Brügge, G. (2016). TTIP: The truth about the Transatlantic Trade and Investment Partnership. London: Polity.

de Wilde, P. (2011). No polity for old politics? A framework for analyzing the politicization of European integration. Journal of European Integration, 33(5), 559-575.

Drieghe, L., \& Potjomkina, D. (2019). EU's value-based approach in trade policy: (Free) trade for all? Global Affairs, 5, 63-72. https://doi.org/10.1080/23340460. 2019.1584539

Eliasson, L. J., \& Garcia-Duran, P. (2017). Why TTIP is an unprecedented geopolitical game changer, but not a Polanyian moment. Journal of European Public Policy, 24(10), 1522-1533.

Eliasson, L. J., \& Garcia-Duran, P. (2019). Civil society, rhetoric of resistance, and transatlantic trade. New York, NY: Palgrave Pivot.

European Commission. (2012-2016). Documents archive (speeches on TTIP, Multiple, 1 December 2012-30 July, 2016). European Commission. Retrieved from http://trade.ec.europa.eu/doclib/cfm/doclib_ results.cfm?key=de\%20gucht\%2C\%20Malmstr\%C3 \%B6m\&opt=1\&dis=50\&lan=all\&ty=Speeches\%20 and\%20articles\&sta $=1 \&$ en $=50$ \&page $=1$ \&year1=01/ $01 / 2013 \&$ year $2=30 / 07 / 2016 \&$ sector $=$ all\&country $=$ all\&langld=EN

European Commission. (2015). Trade for all. Towards a more responsible trade and investment policy. Brussels: European Commission. Retrieved from http:// trade.ec.europa.eu/doclib/docs/2015/october/ tradoc_153846.pdf

European Commission. (2016-2017). Documents archive (speeches on TTIP and on policy, Multiple, 1 September 2016-13 September 2017. European Commission. Retrieved from http://trade.ec.europa. eu/doclib/cfm/doclib_results.cfm?key=Malmstr\%C3 \%B6m\&opt=1\&dis=50\&lan=all\&ty=Speeches $\% 20$ and\%20articles\&sta=1\&en=50\&page=1\&year1=09/ 01/2016\&year2=13/09/2017\&sector=all\&country= all\&langld=EN

European Commission. (2017a). Report on the implementation of the trade policy strategy Trade for All: Delivering a progressive trade policy to harness globalisation (COM(2017) 491 final). Brussels: European Commission.

European Commission. (2017b). A balanced and progressive trade policy to harness globalisation (COM(2017) 492 final). Brussels: European Commission.

European Commission. (2018, June 7). EU trade defence: Stronger and more effective rules enter into force [Press release] Retrieved from https://ec.europa.eu/ commission/presscorner/detail/en/IP_18_3973

Friends of the Earth Europe. (2016). Fears of TTIP threat to democracy, as key documents published. Friends of the Earch Europe. Retrieved from http://www. foeeurope.org/fears-TTIP-threat-to-democracy210316

Garcia-Duran, P., \& Eliasson, L. J. (2018a). Supporters' responses to contested trade negotiations: The European Commission's rhetoric on the Transatlantic Trade and Investment Partnership. Cambridge Review of International Affairs, 30(5/6), 489-506.

Garcia-Duran, P., \& Eliasson, L. J. (2018b). Squaring the circle: Assessing whether the European Union's pursuit of bilateral trade agreements is compatible with promoting multilateralism. Journal of Self-Governance and Management Economics, 6(1), 7-32.

Gheyle, N. (2019). Trade policy with the lights on: The origins dynamics, and consequences of the politicization of TTIP (Doctoral dissertation). Ghent University, Ghent, Belgium.

Gheyle, N., \& De Ville, F. (2017). How much is enough? Explaining the continuous transparency conflict in TTIP. Politics and Governance, 5(3), 16-28.

Hirschman, A. (1991). The rhetoric of reaction: Perversity, futility, jeopardy. Cambridge: Belknap Press.

Hix, S. (2006). Why the EU needs (left-right) politics? Policy reform and accountability are impossible without it (Policy Paper No. 19). Paris and Berlin: Notre Europe Institut Jacques Delors.

Hooghe, L., \& Marks, G. (2009). A postfunctionalist theory of European integration: From permissive consensus to constraining dissensus. British Journal of Political Science, 39(1), 1-23.

IG Metal. (2014, March 4). Freihandelsabkommen sofort stoppen [Stop free trade agreements immediately] [Press release]. Retrieved from http://isds.bilaterals. org/?freihandelsabkommen-eu-usa\&lang=en

Jacoby, W., \& Meunier, S. (2010). Europe and the management of globalization. Journal of European Public Policy, 17(3), 299-317.

Kohlbacher, F. (2006). The use of qualitative content analysis in case study research. Forum: Qualitative Social Research, 7(1), 1-30.

Laursen, F., \& Roederer-Rynning, C. (2017). Introduction: 
The new EU FTAs as contentious market regulation. Journal of European Integration, 39(7), 763-779.

Meunier, S. (2007). Managing globalization? The EU in international trade negotiations. Journal of Common Market Studies, 45(4), 905-926.

Meunier, S., \& Nicolaïdis, K. (2006). The European Union as a conflicted trade power. Journal of European Public Policy, 13(6), 906-925.

Peterson, J. (1995). Decision-making in the European Union: Towards a framework for analysis. Journal of European Public Policy, 2(1), 69-93.

Scholte, J. A. (2000). Cautionary reflections on Seattle. Millennium: Journal of International Studies, 29(1), 115-121.

Seattle to Brussels Network. (2015, June 10). An open letter to the governments of EU-CELAC. Seattle to Brussels Network. Retrieved from http://s2bnetwork.org/ an-open-letter-to-the-governments-of-eu-celac

Siles-Brügge, G. (2018). Transatlantic investor protection as a threat to democracy: The potency and limits of an emotive frame. Cambridge Review of International Affairs, 30(5/6), 464-488.

van Loon, A. (2020). The selective politicization of transatlantic trade negotiations. Politics and Governance, 8(1), 325-335.

Young, A. (2017). The new politics of trade: Lessons from TTIP. Newcastle: Agenda.

Young, A. (2018). Introduction: The politics of deep integration. Cambridge Review of International Affairs, 30(5/6), 453-463.

Young, A. (2019). Two wrongs make a right? The politicization of trade policy and European trade strategy. Journal of European Public Policy, 26(12), 1883-1899.

Zürn, M. (2014). The politicization of world politics and its effects: Eight propositions. European Political Science Review, 6(1), 47-71.

\section{About the Authors}

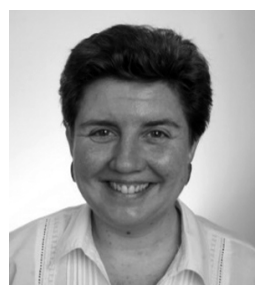

Patricia Garcia-Duran is Associate Professor at the University of Barcelona (Department of Economic History, Institutions and Policies and World Economy). She is also Researcher at the Observatory of European Foreign Policy at the Barcelona Institute of International Studies (IBEI). In recent years, her work has focused on EU trade policy and the World Trade Organization. She has published in several refereed journals, including the Journal of European Public Policy, Journal of European Integration and the Journal of World Trade.

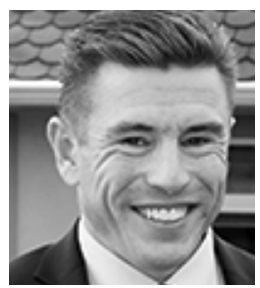

Leif Johan Eliasson is Professor of Political Science at East Stroudsburg University. His research focuses on European trade policy and transatlantic trade relations. In addition to three books, he has published in journals such the Journal of European Public Policy, Journal of European Integration, World Economy, and the Journal of World Trade.

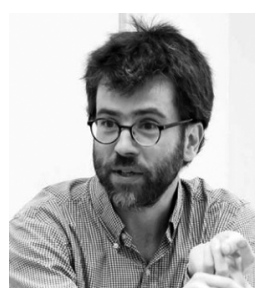

Oriol Costa is Associate Professor of International Relations at the Autonomous University of Barcelona (UAB). He is also a Senior Research Associate at the Barcelona Institute of International Studies (IBEI). His research deals with EU external relations, and has focused more recently on whether and how it has become more politicized and contested. He has published in journals such as Journal of European Public Policy, Comparative European Politics, Cooperation and Conflicts, Mediterranean Politics, and Cambridge Review of International Affairs. 